\title{
The Caddoan Archaeology of the Sabine River Basin during the Middle Caddoan Period
}

Timothy K. Perttula

Heritage Research Center, Stephen F. Austin State University

J. Brett Cruse

Follow this and additional works at: https://scholarworks.sfasu.edu/ita

Part of the American Material Culture Commons, Archaeological Anthropology Commons, Environmental Studies Commons, Other American Studies Commons, Other Arts and Humanities Commons, Other History of Art, Architecture, and Archaeology Commons, and the United States History Commons

Tell us how this article helped you.

This Article is brought to you for free and open access by the Center for Regional Heritage Research at SFA ScholarWorks. It has been accepted for inclusion in Index of Texas Archaeology: Open Access Gray Literature from the Lone Star State by an authorized editor of SFA ScholarWorks. For more information, please contact cdsscholarworks@sfasu.edu. 


\section{The Caddoan Archaeology of the Sabine River Basin during the Middle Caddoan Period}

\section{Creative Commons License}

\section{(c) (1) \&}

This work is licensed under a Creative Commons Attribution-NonCommercial 4.0 International License 


\section{The Caddoan Archaeology of the Sabine River Basin during the Middle Caddoan Period}

\section{Timothy K. Perttula and J. Brett Cruse}

Compared to the earlier and later parts of the prehistoric Caddoan archaeological record in Northeast Texas, archaeologists do not know much about the Middle Caddoan period (ca. A.D. 1200-1400) in the Sabine River basin. During the last few years, however, new archaeological information on settlements, subsistence, and the diverse material culture record suggest that the era was a time of significant cultural change for Caddoan peoples living in the upper and middle Sabine River basin (Figure 1).

\section{Settlement}

Of considerable significance is the recognition that Caddoan settlements at this time include large communities (i.e., those covering more than about 3-5 acres), in addition to the small hamlets and farmsteads. Certainly the large village at Oak Hill (41RK214)-containing at least 42 circular and rectangular structures (Figure 2)--is unprecedented, as is the village planning data (a central plaza surrounded by structures, with a mound at one end, and a large, distant midden), but other large communities may have been present at other sites within the basin (such as Jamestown [41SM54], 41HS74, and Musgano [41RK19]). All occur along tributaries of the Sabine River, some near the headwaters of the tributary streams, and they are present in considerable numbers (Figure 3 ).

\section{Subsistence}

Maize and other cultivated plants seem to become more common around ca. A.D. 1300 , in the heart of the Middle Caddoan period, in the Sabine River basin (at least north of Toledo Bend Reservoir). Maize was common at Oak Hill village in contexts dating between ca. A.D. 1150-1370, as were a series of apparent above-ground small granary structures along the eastern edge of the site (see Figure 2), and was more abundant at Spoonbill (41WD109) at this time (ca. A.D. 1220-1400) compared to the paleobotanical samples from the Early Caddoan component at the site. Stable carbon isotope data would be needed to directly measure the contribution of maize to the Caddoan diet at this time.

\section{Dating}

Middle Caddoan period components with calibrated $\mathrm{C}^{14}$ dates include $41 \mathrm{HS} 74$ (cal AD 1159-1520, one sigma, [0.87 probabilityl); Oak Hill Village (3 dates between cal AD 1154-1294 and 5 dates between cal AD 1280-1436 [several other dates from postholes have recently been obtained from the site that also fall in these intervals; Robert Rogers, 1997 personal communication]); Redwine (41SM193, cal AD 1312-1350 [0.49] or cal AD 1388-1423 [0.51]); Carlisle (41WD46, cal AD 1387-1443 [0.65]); Spoonbill (3 dates between cal AD 1228-1395); and McKenzie (41WD55, 5 dates between cal AD 1298-1400 and 3 dates between cal AD 1381-1470). Several other Middle Caddoan period components from the proposed Big Sandy Reservoir and the Crews site (4lWD371) have thermoluminescence dates on ceramic sherds.

\section{Mounds}

Substructural mounds were built by Middle Caddoan peoples at Hudnall Pirtle, McKenzie, Bryan Hardy (41SM55), Oak Hill Village, and Jamestown, as well as 4IWD7 and Colony Church (41RA31), although the latter two are not well known. The distributions of the mound centers closely corresponds to the three main clusters of Middle 

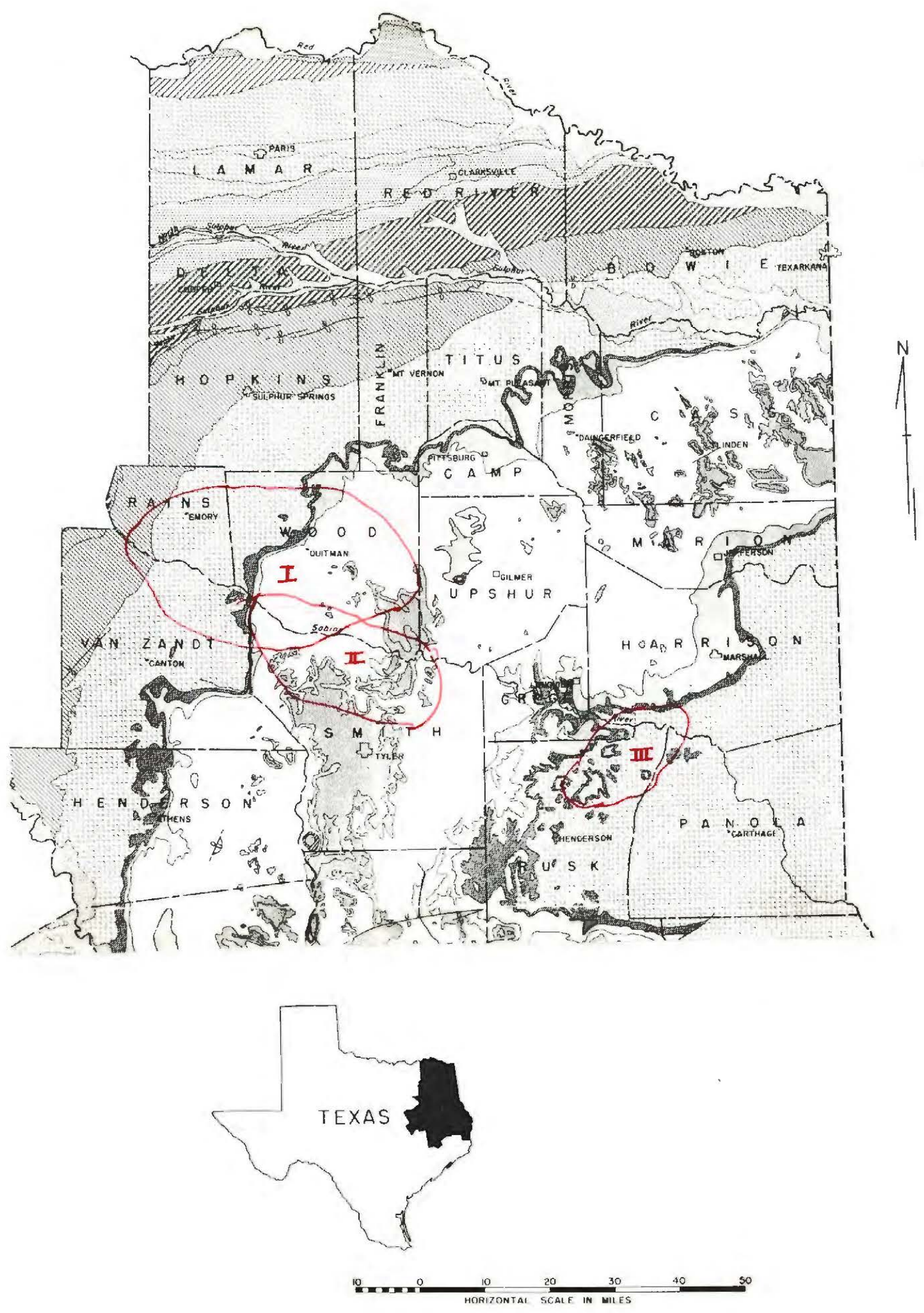

Figure 1. Distribution of Middle Caddoan Components in the upper and middle Sabine River basin 


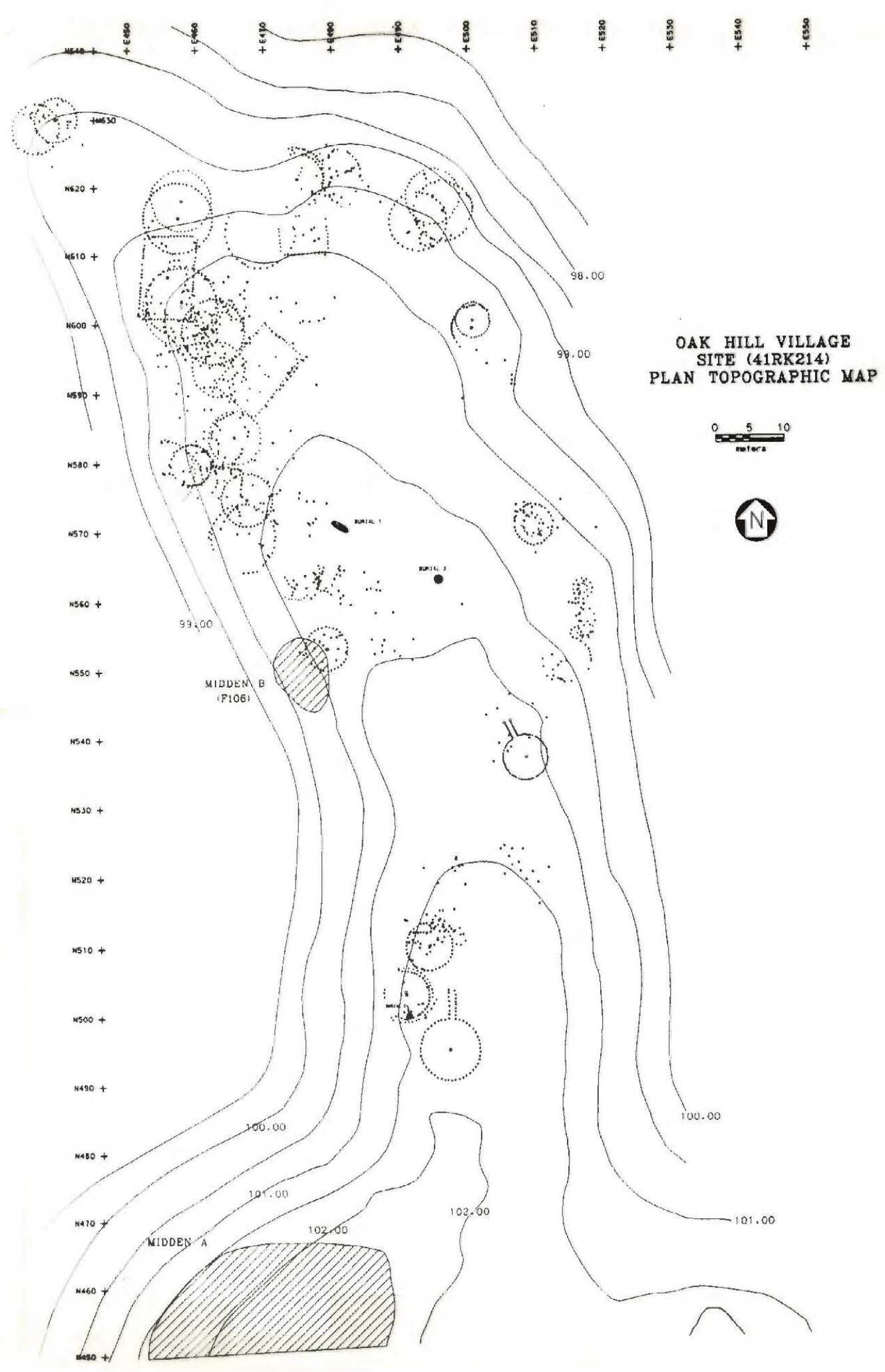

Figure 2. Structures and Midden Deposits at the Oak Hill Village Site (41RK214). 


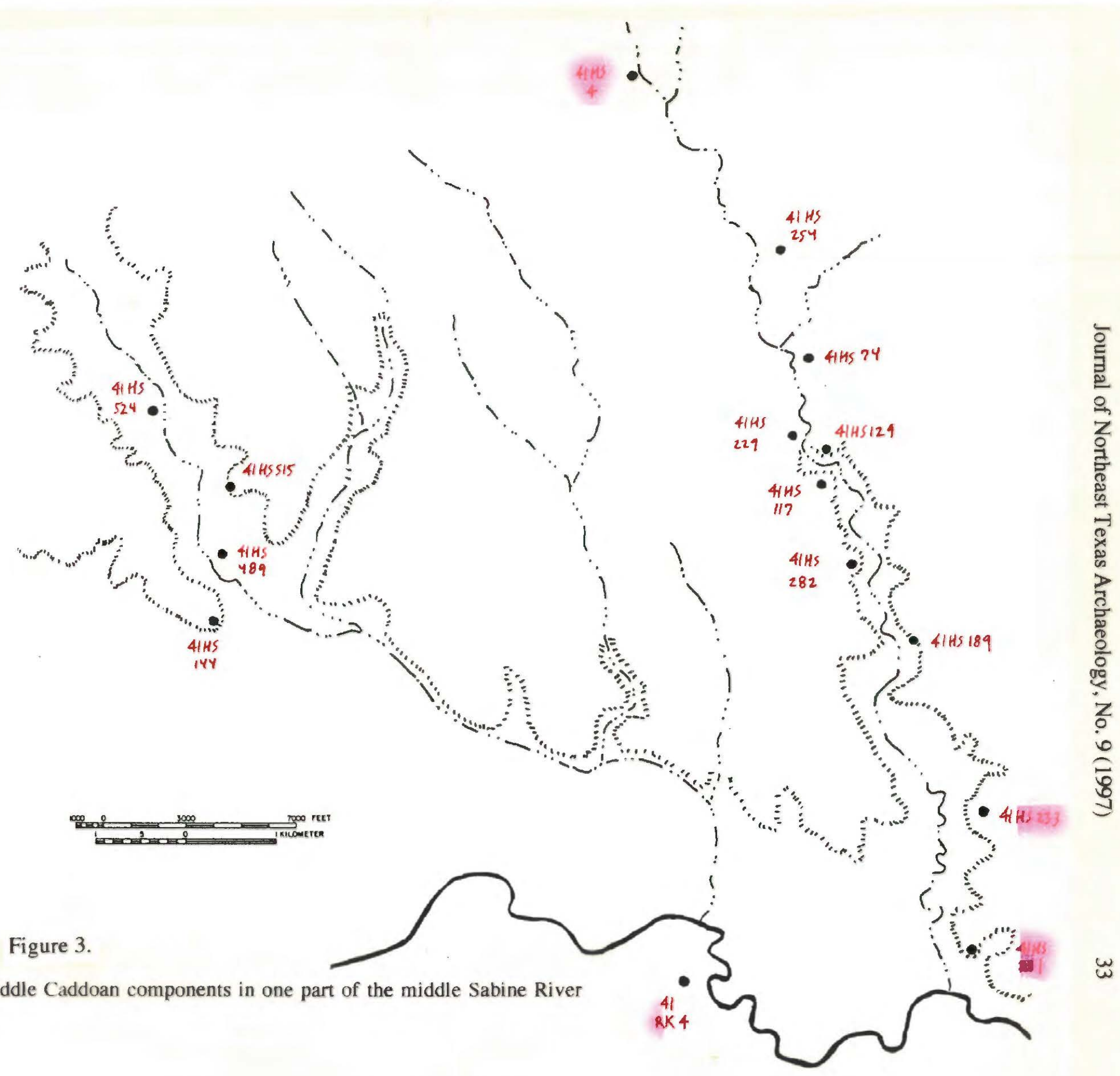


Caddoan period settlements discerned from ceramic stylistic differences within the upper and middle Sabine River basin (Figure 4). As with the larger village communities, the mound centers at this time occur principally along tributaries of the Sabine River--such as Lake Fork Creek, Ray Creek, and Mill Creek--rather than along the Sabine River itself. Whether they represent aspects of a hierarchical system of related communities is not known (Figure 5).

\section{Mortuary Practices}

Small cemeteries are prevalent at many of the Middle Caddoan period communities throughout the basin, and in general these may be interpreted as small family cemeteries of a few individuals $(<10)$. Larger cemeteries have been reported from a few sites (41WD20, 41HS144), and shallow shaft tombs from Charlie Crews (41WD371) with multiple individuals and numerous grave goods hint at changes in mortuary practices during the period.

\section{MaterialCulture}

Ceramics constitute the best available, and most useful, material culture record to distinguish the Middle Caddoan period archaeology from earlier and later periods. Nevertheless, the picture of stylistic diversity and changes in style across the Sabine River basin has not been clearly defined. We see at least three distinctive ceramic assemblages of Middle Caddoan period age (see Figures 1, 4, and 5) in the Sabine River basin (above Toledo Bend Reservoir):

1 (pertinent examples include Yarbrough [4I VN6, Area B], Spoonbill [41WD109], Thomas Moody [4IWD577], and Limerick [41RA8]) Affiliations with the Sanders phase, dominated by diagonal and cross-hatched incised and engraved bowls, beakers, and jars; pendant triangle motifs; Maxey Noded Redware bottles; redslipping is common; interior thickened rims and lip notching, some scalloped rims; Monkstown Fingernail Impressed is present; brushed vessels virtually absent.

II (pertinent examples include Carlisle [41WD46], 4IVN6, Area A, 4IWD518. Bryan Hardy [41SM55]) Sanders Plain, Sanders Engraved, Maxey Noded Redware, Canton Incised, neck banding; ladder engraved, and engraved pendant triangles; thickened rims; assortment of punctated, appliqued, and brushed sherds. Diverse engraved motifs--combinations of ladders, pendant triangles, branches, and semi-circular--on bottles and carinated bowls.

III (pertinent examples, Oak Hill Village [41RK214], 41RK342, 41HS74, Musgano [41RK19], 41RK30, and 41HS489) Abundant brushing, ranging from 30-70 percent of all decorated sherds; red-slipping is virtually absent; engraved ladders and scrolls (Haley Engraved, Carmel Engraved, and Maddox Engravedlike); Pease Brushed-Incised; cross-hatched incised; the engraved rattlesnake motif is noted at several sites, including 41RK214 and 41HS74 (Figure 6), and links these sites to Middle Caddoan period sites in the Cypress Creek basin (see Nelson and Turner, this symposium); Haley variety of Red River pipe, and elbow pipes with a distinctive flat bowl. 


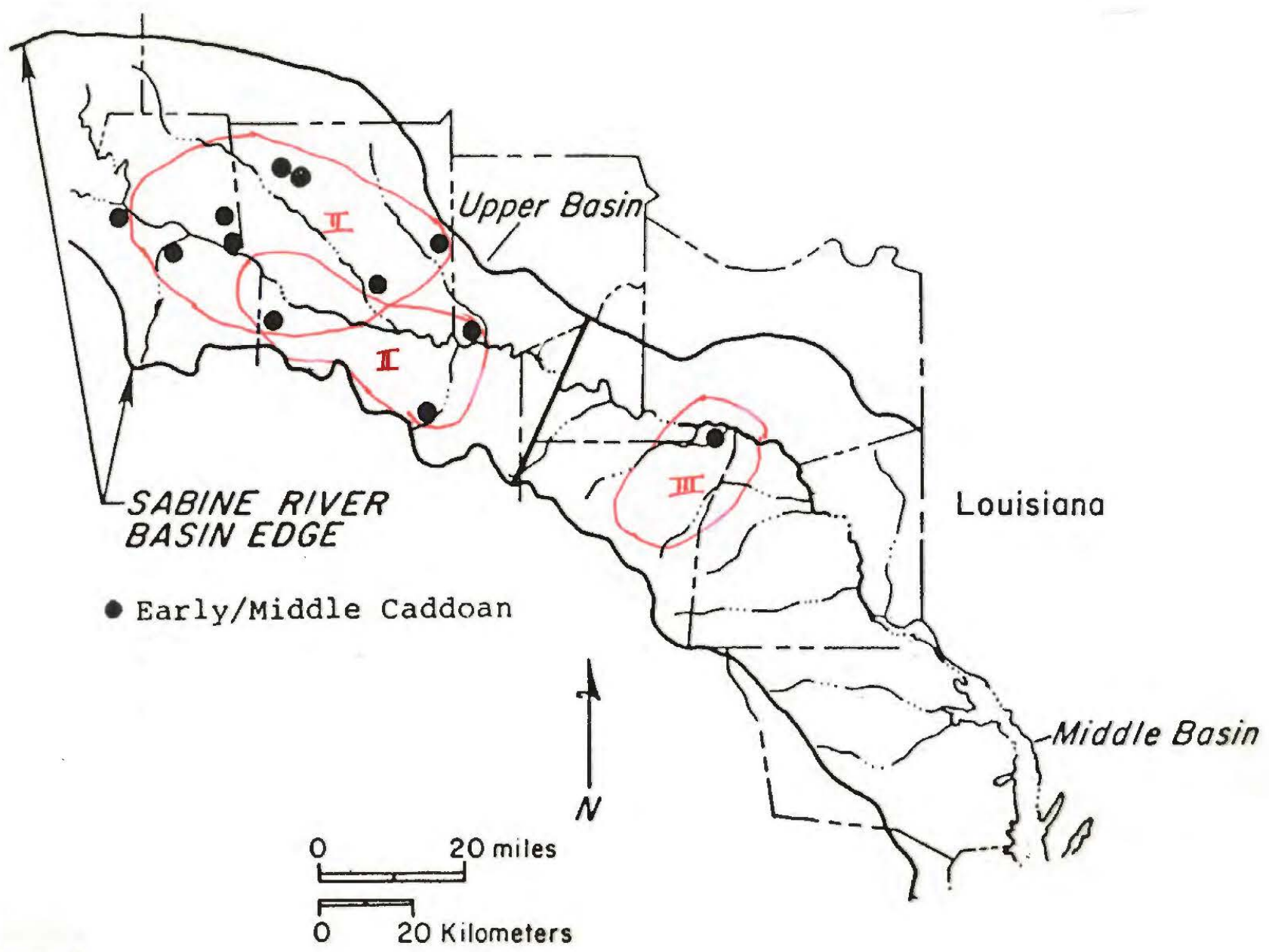

Figure 4.

Comparison of Early and Middle Caddoan mound centers and Middle Caddoan ceramic assemblages in the upper and middle Sabine River basin 


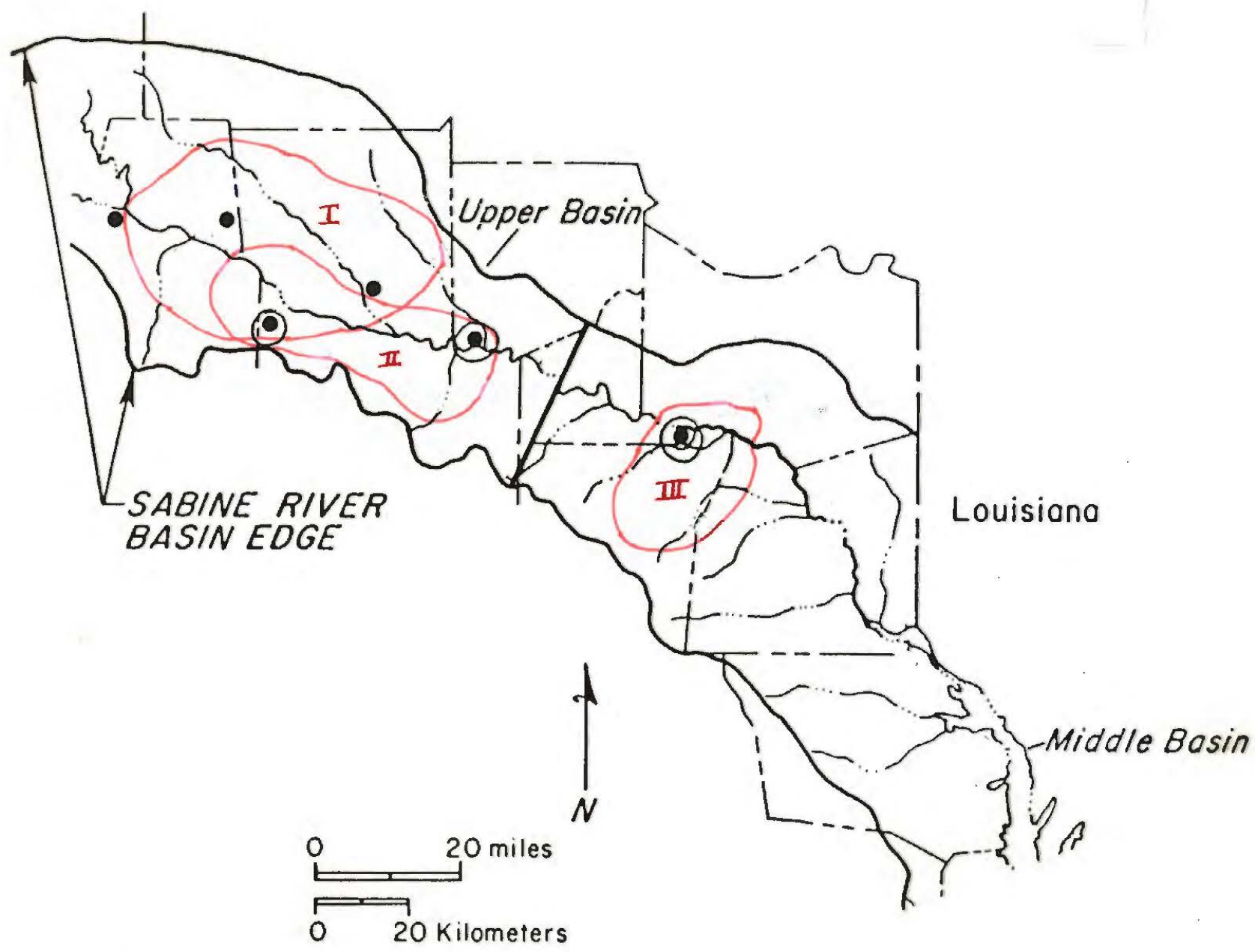

Figure 5.

○ premier center

Comparison of premier and subsidiary mound centers and Middle Caddoan ceramic assemblages in the upper and middle Sabine River basin 


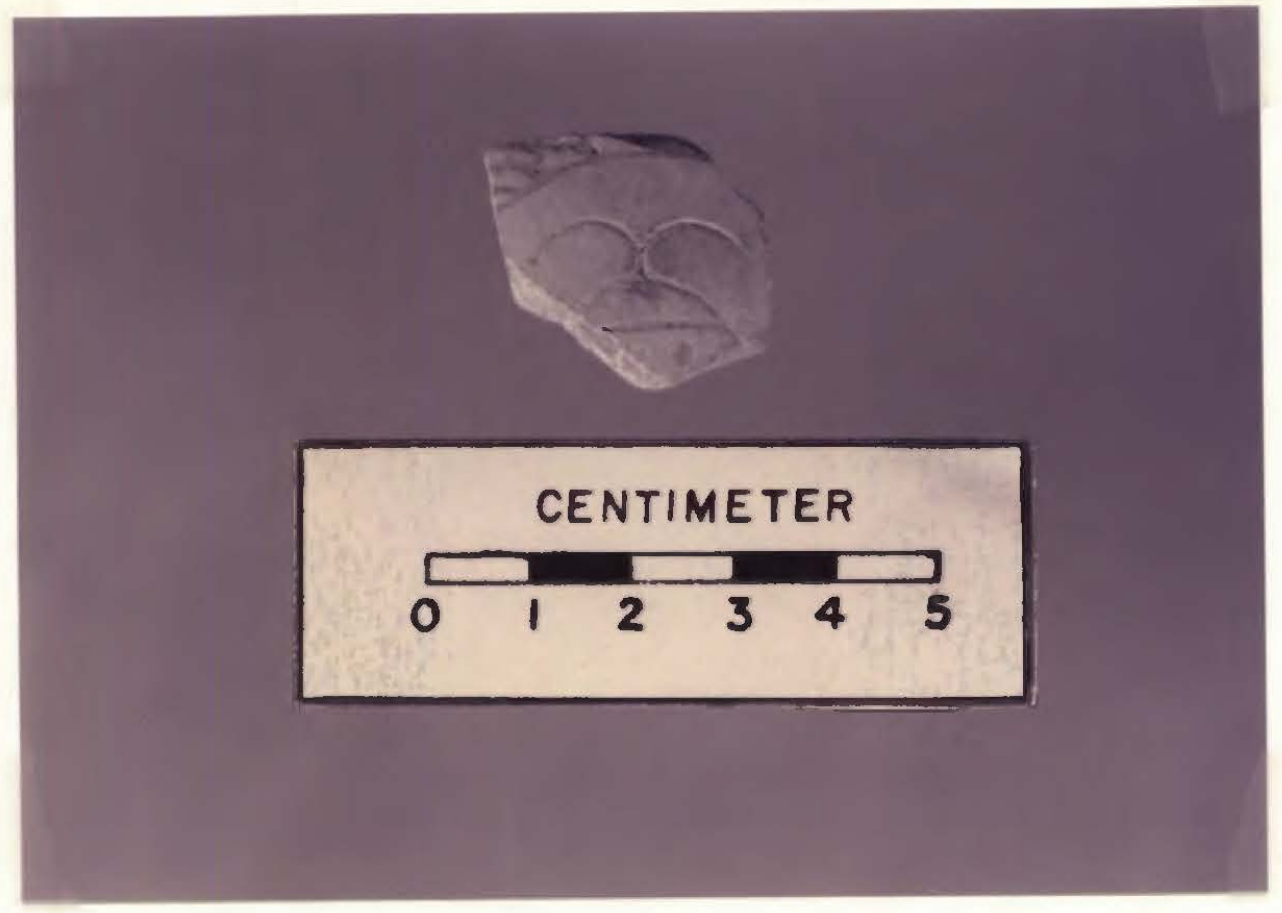

Figure 6. Engraved Rattlesnake Motif on a Body Sherd from the Oak Hill Village site (41RK214).

\section{Pertinent References}

Bruseth, J. E. and T. K. Perttula

1981 Prehistoric Settlement Patterns at Lake Fork Reservoir. Texas Antiquities Permit Series, Report No. 2. Southern Methodist University and Texas Antiquities Committee, Dallas and Austin.

Clark, J. W. and J. E. Ivey

1974 Archeological and Historical Investigations at Martin Lake, Rusk and Panola Counties, Texas. Research Report No. 32. Texas Archeological Survey, Austin.

Granberry, D.

1995 William T. McKenzie Mound. The Record 46 (No. 1):1-18.

Heartfield, Price and Greene, Inc.

1988 DataRecovery at Site 41 HS74. Heartfield, Price, and Greene, Inc., Monroe.

Johnson, L., Jr.

1962 The Yarbrough and Manton Miller Sites of Northeastern Texas, with a Preliminary Definition of the La Harpe Aspect. Bulletin of the Texas Archeological Society 32:141-284.

Perttula, T. K., B. D. Skiles, and B. C. Yates

1993 The Carlisle Site (41WD46), a Middle Caddoan Occupation on the Sabine River, Wood County, Texas. Notes on Northeast Texas Archaeology, No. 1:34-62. 